\title{
THE DETERMINING OF THE FORCE FOR CORN-COBS SEPARATION
}

\author{
V. Hruban, Candidate of Technical Sciences, Associate Professor \\ ORCID: 0000-0003-0753-565X \\ V. Havrysh, Doctor of Economical Sciences, Professor \\ ORCID: 0000-0001-7055-1674 \\ Mykolayiv National Agrarian University \\ A. Kalinichenko, Doctor Habilitated, Professor \\ ORCID: 0000-0001-7342-3803 \\ University of Opole, Poland
}

There has been an increase in demand of corn in the world. This requires the use of high-performance agricultural machinery, including combine harvesters. However, corn harvesters have high grain losses and their apparatuses must be improved. The aim of the article is justification of corn picker operation by developing a mathematical model of the process of cobs separation in the complex combination several forces. To verify this model the results of the simulation were compared to experimental data. The wave theory has proved to be more accurate compared to the static model. The results of the theoretical researches of the methods of corn-cobs separation from stems are given and mathematical models are worked out. The technological process of corn-cobs separation fulfilled by the combination of different forces is considered, and the valuation of the resulting tension. The technological process of cobs separation is considered in combination of many forces, and making assessments of the resultant tension. Further research will be focused on the intensification of this process by the integration of stretching the stalk together with its twisting.

Keywords: corn, cob, separation, cob separation system, mathematical model.

The statement of the problem. For the long time corn has ranked third among cereals in the world [1]. Corn is the world's largest crop and important feedstock for food, fodder and ethanol production. World ethanol production is expected to be doubled in the nearest future. Moreover, corn cobs are agricultural biomass and they can be feedstocks for renewable energy industries to abate the current energy and the greenhouse gas problems. Corn cobs can be used for producing variety of energy and fuels such as heat, electricity, gaseous, liquid and solid fuels, as well as a number of chemical products. It results in an increase of corn demand. The growth is expected to occur in Ukraine too, which currently is a large producer in Europe.

One of the important technological processes which regulate qualitative and quantitative indexes while harvesting corn for seeds is the separation of cobs from stems. The most widespread commercial method of separating is the cutting with a sharp blade. Unfortunately, this cutting operation may sever the upper part of the cob. It results in reducing the harvest obtained. The losses are around $20 \%$. However, installed on the majority of the world's corn-harvesting machines picker-strapping cobseparating apparatus are not on appropriate level of quantitative indexes of operation. The improper quality of this technological process fulfilling is explained mostly by the fact that their operation is based on the principle of separation at the expense of longitudinal stretching that leads to its rupture. But in some cases the resistance of the stem rupture may be less than in the stalk. This may lead to harvest losses by free cobs [2]. In addition, due to the considerable tension of the stalk and its violent destruction, we cannot exclude the possibility of throwing the cob outside the reaper after separation.

That's why the development of a new design of a cob separation apparatus is an important scientific problem. Its solving would give a possibility to increase general technical level of corn-harvesting machines.

Analysis of recent research. Scientists of various research institutions carried out a significant amount of work to improve the cob-separating apparatus (particular elements of this question were solved in the design bureau of Kherson Combine Plant).

(C) Hruban V., Havrysh V., Kalinichenko A., 2021 
Classification of corn cob recovery systems are within the following domains: separation method, separation location, and storage location. The corn cobs can be separated by the following methods: mechanical, pneumatic, and combined. This process can be carried out on board the harvester and in stationary conditions. In Ukraine combine based methods of separation are used.

There are patents to solve this problem. They propose the following ways: removing intact whole kernels of corn from the cob [3]; a dual action corn cob separation [4]; the use of conveyer system [5].

On the basis of the research a common thought appeared that the most promising way to improve cob-separating apparatuses is stabilization of the parameters of the cob-separating process. That is, the transition from structures in which the separation of the cobs is random, chaotic in nature, to structures in which these processes are predicted on the basis of certain regularities [6].

Researchers have studied the mechanical properties of corn stalk. Threshing forces of corn stalk have been tested by Li, X.P. and Gao, L. X. [7], Li, X.F. et al. [8], Gao, L.X. et al. [9] and Dominguez, H.D.A. et al. [10]. In the above publications the effects of a number of factors were considered.

To design agricultural and processing machines requires specific of knowledge, including mechanical properties of biological materials. They are necessary to develop agricultural machines that operate in aggressive and severe conditions. Therefore mechanical properties of biological materials produced by agriculture have been the object of studies. The above knowledge is useful for the development of technological processes [11].

Akritidis, C. D. has revealed the mechanical factors affecting the cut of corn stalks [12]. He analyzed the stalk cutting taking into account the mechanical properties of the corn stalk and the cutting blade. Esehaghbeygi A. [13] carried out the measurement of the shear stress of stalk for the following conditions: different moisture content; different cutting heights of stalk. The optimal knife oblique for the lowest shearing pressure has been found. Its value was determined at 30 degree. Prasad and Gupta [14] studied the shearing force for cutting corn stalks. They found that the maximum shearing force depends on the shearing velocity.

Miu, P. [15] found the impact of a number of factors (mechanical and physical properties of stalks, the mechanical forces exerted through the harvester combine, plant curvature, and pick up cobs) on the cutting process.

To design agriculture machines it is necessary to know the physical and mechanical properties of the plants. The geometrical dimensions, ultimate tensile strength, angle of friction of corn cob, etc. are essential for the designing of harvester units.

Design engineers need reliable and simple mathematical apparatus to create effective corn harvesters and corresponding equipment. That is why the aim of this study is to develop the mathematical model for the cob-separating in the cases of static and dynamic loads with choosing of the best option.

The results of the research. The conventional cob-separating apparatus operation process was considered. They use the principle of the stretching of a stalk. The corn stalk was considered as a tensile elastic constant section thread of permanent intersection. It has area of S0. This physical model was selected to develop the mathematical model.

This thread is stretched by pull rollers. The stretching process continues until the cob meets the stripper plates. The process from the moment of contact with the stripper plates to the moment of separation of the cob was considered. The moment of contact was accepted as the origin of time $(t=0)$. The pulling force of the rollers is replaced with the applied force No to the free end of the $\operatorname{cob}(\mathrm{z}=1)$. The left side of the cob is clamped with stripper plates and could be considered to be fixed between the stripper plates. The length of the cob is equal to 1 .

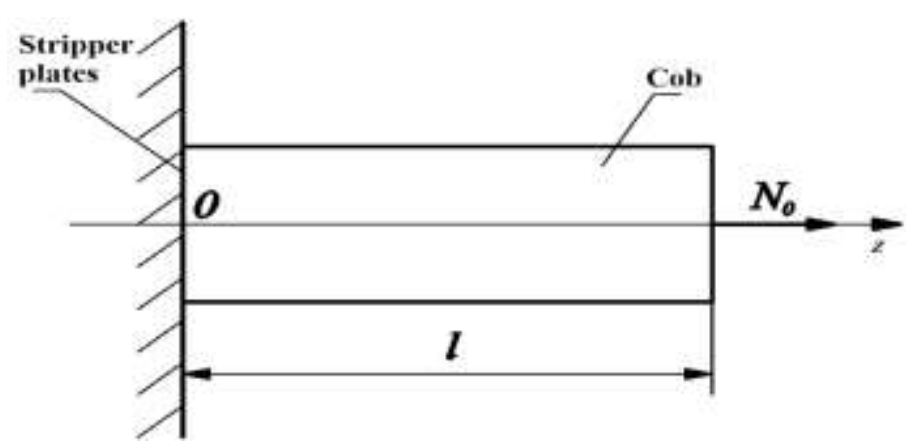

Figure 1 - The calculation scheme 
In the case of the stalk static load, a tension of the same length appears in the pattern thread [16]:

$$
\sigma=\frac{N_{0}}{S_{0}}, \mathrm{~Pa},
$$

where $S_{0}$ is the section of the stalk, $\mathrm{m}^{2}$.

Initial conditions are considered to be zero, and at the initial time $(\mathrm{t}=0)$ they are described by expression

$$
t=0 ; \quad u(0, z)=0 ; \quad \frac{\partial u(0, z)}{\partial t}=0,
$$

where $t$ is the time, sec;

$u$ is the function of longitudinal deformations, m;

$z$ is the longitudinal coordinate, $\mathrm{m}$.

The boundary conditions are the following: $z=0$, $u=(0, t)$. In this point the stalk is clamped. No force is applied to the other end of the cob. Its longitudinal coordinate is $z=1$. The maximum value of the stalk deformation $\mathrm{u}(t, z)$ is reached at the moment of time

$$
t_{l}=2 l / a_{0}, \mathrm{sec},
$$

where $\mathrm{a}_{0}$ is the speed of sound into the plant, $\mathrm{m} / \mathrm{s}$.

The maximum value of the stalk deformation is determined by the equation

$$
u_{\max }=\frac{16 N_{0} l}{E S \pi^{2}} \sum_{n} \frac{1}{n^{2}},(\mathrm{n}=1,3,5, \ldots), \mathrm{m},
$$

where $l$ is the cob length, m;

$E$ is the modulus of elasticity (Young's module) of the corn cob, $\mathrm{Pa}$.

Loay Al-Zube et al. studied the modulus of elasticity values of the dry maize stalks obtained using different mechanical loading modes. All methods showed that the modulus of elasticity ranges from 6 to $16 \mathrm{GPa}$ [17].

In the case of the dynamic load, the longitudinal function is equal to:

$$
u_{\max }=\frac{2 N_{0} l}{E S_{0}}, \mathrm{~m} .
$$

In the case of the static load, the longitudinal function is halved:

$$
u_{\max }=\frac{N_{0} l}{E S_{0}}, \mathrm{~m}
$$

The maximum force in the thread can be found by the following expression:

$$
T_{\max }=\frac{8 N_{0} E S_{0}}{\pi q_{0} a_{0}^{2}} \sum_{n} \frac{(-1)^{\frac{n-1}{2}}}{n}, \mathrm{~N},
$$

where $q_{0}$ is the weight per unit length of the thread (cob), $\mathrm{kg} / \mathrm{m}$.

Thus, the dynamic destruction of the thread by force $N_{o}$ will give an effort at the point of fastening the stalk and the cob [16]:

$$
T_{\max }=2 N_{0}, \mathrm{~N} .
$$

Thus the dynamic force is twice the force under static load. The tension in the thread when it is destroyed is

$$
\sigma_{\max }=\frac{T_{\max }}{S}=\frac{2 N_{0}}{S}, \mathrm{~Pa} .
$$

The separating of cobs in the in the piker-strapping apparatus is accompanied by an impact to the stripper plates. Therefore, the next stage of this study is the investigation of this phenomenon.

The interaction of a cob and the stripper plates was considered as a strike of an elastic rod (the moving speed is equal to $v_{0}$ ) on a stationary plate (fig. 2). The weight of the stationary plate exceeds the weight of the rod. We accept the following interaction conditions:

- the stripper plates do not deform;

- the stripper plates remains stationary.

Two models of strike were considered. In the first case, the wave processes in the cob is neglected. We believe that the cob deforms along the whole length at the same time. The distribution of the tension in the cob can be determined by the equation:

$$
\sigma(z)=\sigma_{0} \frac{z}{l}, \mathrm{~Pa},
$$

where $z$ is the coordinate whose size differs from the free end of the stalk;

$\sigma_{0}$ is the tension at the base of the cob, $\mathrm{Pa}$;

$l$ is the length of the cob, m;

$\sigma(z)$ is the tension in the point with the coordinate $z, \mathrm{~Pa}$ 


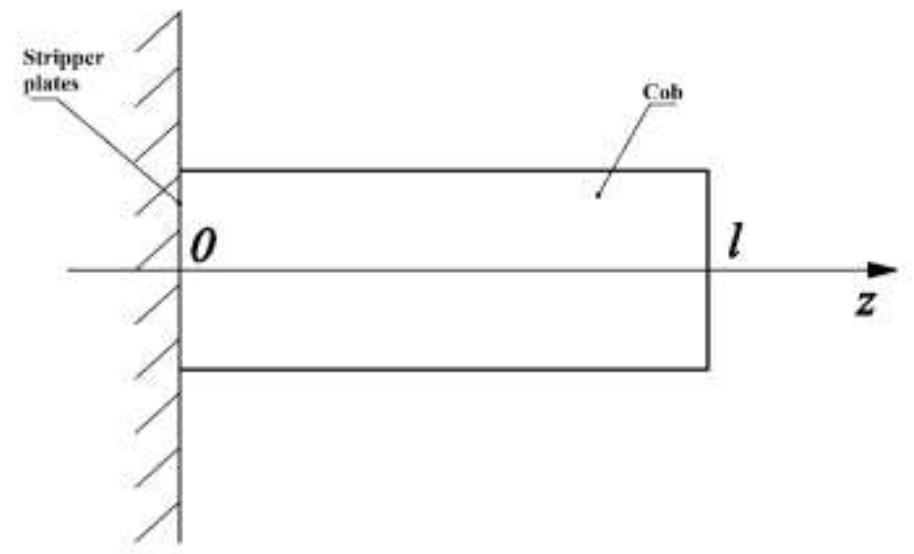

Figure 2 - Scheme of the interaction of the cob and the stripper plates

The force in the cob is determined as:

$$
T(z)=S_{0} \sigma(z), \mathrm{N} .
$$

The full work of cob deformation is:

$$
A=\frac{\sigma_{0}^{2}}{6} \frac{S_{0} l}{E}, \mathrm{~J},
$$

Having equated the work of deformation (11) to kinetic energy, we obtain the tension [6]

$$
\sigma_{0}=\sqrt{3} \frac{v_{0}}{a_{0}} E, \mathrm{~Pa} .
$$

where $v_{0}$ is the velocity, $\mathrm{m} / \mathrm{s}$.

Then, substituting (12) in (10), we obtain the expression for determining the force in the cob during the impact:

$$
T=\sqrt{3} \frac{v_{0}}{a_{0}} E S_{0}, \mathrm{~Pa},
$$

We can see from formula (13) that in order to perform the technological process of separation of cobs more effectively, it is necessary to strive in increasing the speed of rotation of the stretching rollers. However, rather high dragging speeds and significant separation efforts lead to the cobs throwing beyond the reaper, thereby reducing the harvest.

In the second case, we solve the same problem using the wave model of the rod. The maximum value of the movement of the right end of the $\operatorname{cob}(z=l)$ is reached by $t=l / a_{0}[18]$ :

$$
u_{\max }=-\frac{8 v_{0} l}{\pi^{2} a_{0}}\left(1+\frac{1}{9}+\frac{1}{25}+\ldots\right)=\frac{v_{0} l}{a_{0}}, \mathrm{~m} .
$$

The maximum force at the point $z=0$ is achieved at the moment of time $t_{1}=l / a_{0}$ is calculated by the expression:

$$
\begin{aligned}
& T_{\max }=-\frac{4 v_{0} E S_{0}}{\pi a_{0}} \sum_{n=1}^{\infty} \frac{(-1)^{n+1}}{2 n-1}=-\frac{v_{0}}{a_{0}} E S_{0}=-v_{0} S_{0} \sqrt{\rho E} \\
& (\mathrm{n}=1,3,5, \ldots), \mathrm{N} .
\end{aligned}
$$

Thus, the exact solution of the problem differs from the approximate one by the multiplier $\sqrt{3}$. The approximate solution gives a higher force.

To analyse the deformation of cob, its physical properties were used. Such data as length, diameter, porosity and angle of friction are necessary for our study. The selected physical properties of corn cobs are shown in Table 2. The length of cob varies from $20.17 \mathrm{~cm}$ to $23.2 \mathrm{~cm}$. And the average length of 21.68 $\mathrm{cm}$ is assumed [19]. The diameters of a corn cob are within the range from 3.78 to $5.69 \mathrm{~cm}$ [19]. The average diameter is $4.94 \mathrm{~cm}$. The porosity of cob ranges from 42.81 to $52.78 \%$. The average repose of angle of corn cobs was 26.76 degrees, and the angle of friction was 32.90 degrees.

Physical properties of corn cobs

\begin{tabular}{|l|c|c|c|c|}
\hline \multicolumn{1}{|c|}{ Parameter } & Unit & Minimum & Maximum & Average \\
\hline Length of corn cob & $\mathrm{cm}$ & 20.17 & 23.2 & 21.68 \\
\hline Diameter of corn cob & $\mathrm{cm}$ & 3.78 & 5.69 & 4.94 \\
\hline Porosity & $\%$ & 42.81 & 52.78 & 46.74 \\
\hline Repose angle of corn cobs & degree & 19.1 & 37 & 26.76 \\
\hline Angle of friction of corn cobs & degree & 28 & 38 & 32.9 \\
\hline
\end{tabular}


The bulk density of whole corn cobs are within the range from 163 to $316 \mathrm{~kg} / \mathrm{m} 3$ [20]. This value depends on species of corn and moisture content. The true density is a function of the bulk density and porosity

$$
\rho_{t}=\frac{100}{100-\varepsilon} \rho_{b}, \mathrm{~kg} / \mathrm{m}^{3},
$$

where $\rho_{\mathrm{b}}$ is the bulk density, $\mathrm{kg} / \mathrm{m}^{3}$;

$\varepsilon$ is the porosity, $\%$.

The deformation chart of the cob and the time dependent force is of significant scientific interest. To find the above, new variables have been introduced

$$
n=2 k-1
$$

And the dimensionless time $\tau=a_{0} t / l$.

Moreover, to make the equation more compact new abbreviations are applied $u_{o}=v_{0} l / a_{0}$, and $T_{o}=E S_{0} * v_{0} / a_{0}$.

Then equation for the longitudinal deformation can be represented in the following form

$$
u(l, \tau)=2 u_{o} \sum_{k=1}^{\infty} \frac{(-1)^{k-1}}{\left[\frac{\pi(2 k-1)}{2}\right]^{2}} \sin \left[\frac{\pi(2 k-1) \tau}{2}\right], \mathrm{m}
$$

And the equation for the force is

$$
T(0, \tau)=-2 T_{o} \sum_{k=1}^{\infty} \frac{\sin \left[\frac{\pi(2 k-1) \tau}{2}\right]}{\left[\frac{\pi(2 k-1)}{2}\right]}, \mathrm{N} .
$$

For the graphic interpretation of the results of calculating the longitudinal deformation, the dimensionless function was used

$$
\bar{u}(l, \tau)=\frac{u(l, \tau)}{2 u_{0}} .
$$

We introduce a dimensionless function to determine the force

$$
\bar{T}(0, \tau)=\frac{T(0, \tau)}{2 T_{0}} .
$$

The calculation results are shown in Figure 3 and 4.

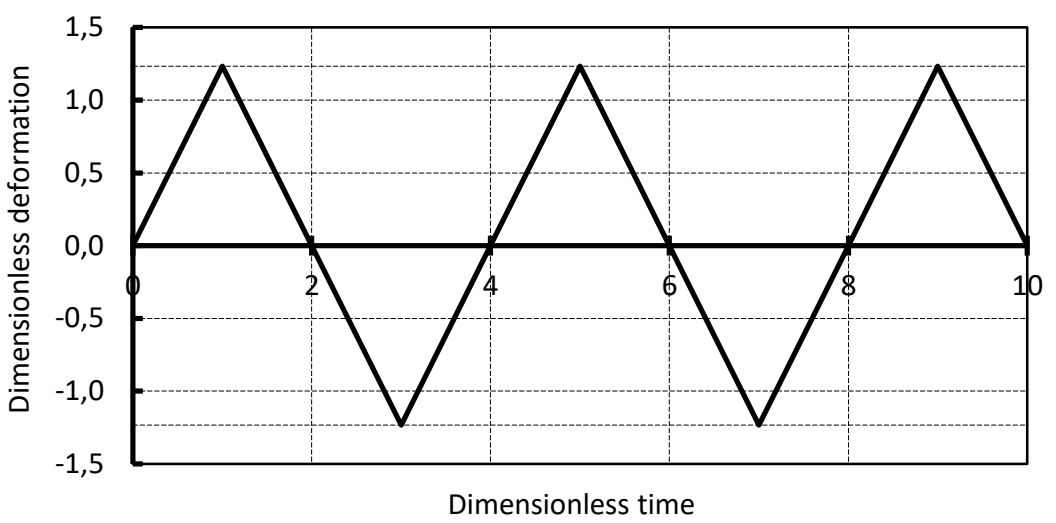

Figure 3. Graph of the deformation in the end of the cob

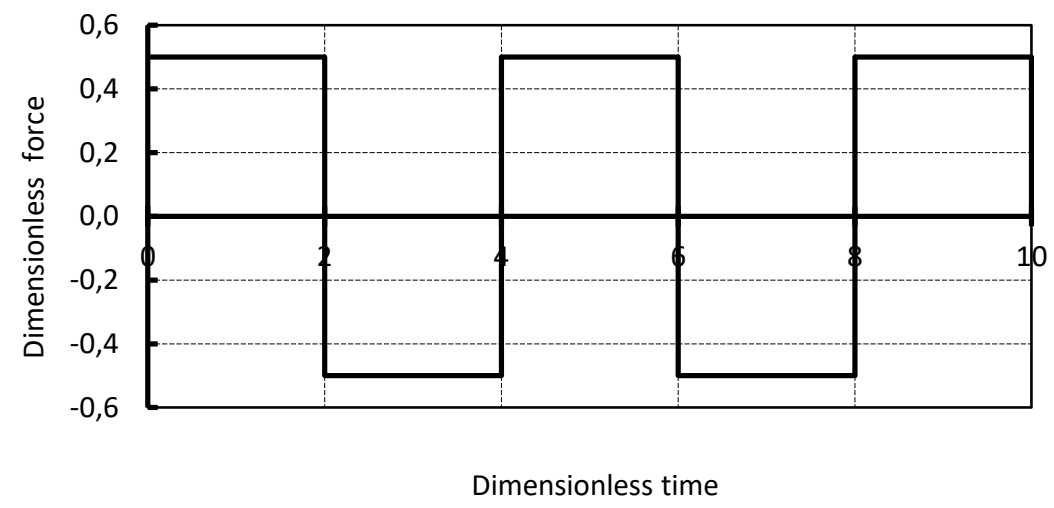

Figure 4. Force in the point of interaction of the cob and the stripper plates

To verify the mathematical model, the pulling force for the separation of a corn cob was calculated and compared to the experimental results. Initial data have been taken from research conducted by Al-Mitewty et al. [21]. The following data were assumed for computation:

- The diameter of stalk is $2.21 \mathrm{~cm}$;

- The weight of a corn cob is $0.42 \mathrm{~kg}$;

- The length of corn cob is $21.68 \mathrm{~cm}$; 
- The diameter of corn cob is $4.94 \mathrm{~cm}$.

Al-Mitewty et al. reported that the pulling force ranged from 307.9 to $330.18 \mathrm{~N}$. Our computations had the following results. In the case of the static load, the pulling force was 355-396 N. The use of the wave theory resulted in a less separating force. This force varies from 290.9 to $324.6 \mathrm{~N}$. The developed mathematical model has good correspondence to experimental data and, therefore, it can be used for the corn harvester design.

Based on the above, we can conclude that the use of wave theory will give more accurate results. This theory more accurately describes the processes that take place in the cob during its separation due to the impact on the stripper plates. However, the impact in the process of cob separation remains undesirable, because as a result of such interaction of the cob with stripper plates there is a high probability of destruction of the cob base. It can result in partial and complete dropping-out of grain during its transportation by corn harvesting machines, thereby increasing the overall yield loss.

Conclusions. To analyze the separating force, the threshing properties were tested. The mathematical model has been developed under quasi-static loading. As the result of the research conducted the mathematical model of major methods of cob separation has been developed, which makes it possible to establish the regularities of the change of the main kinematic parameters of the cob-separating apparatus of the multifactorial action.

If we consider the combination of several forces in the process of cob separation, then one of the promising ways to intensify this process is the integrated use of stretching the stalk together with its twisting. In this case, the torsion will be an additional destructive force.

Further research after checking the received results at a laboratory will focus on the practical implementation of them in the design and manufacture of corn-harvesting machines.

\section{Список використаних джерел:}

1. Sobukola, O. P., Kajihausa, O. E. Onwuka, V. I. and Esan T. A. (2013). Physical properties of high quality maize (Swam 1 variety) seeds (Zea mays) as affected by moisture levels. African Journal of Food Science, 7(1): 1-8.

2. Демко А., Демко О. Чому втрати урожаю - не збитки, а статистика? Пропозиція. 2009. № 9. С. 100-104.

3. George H. Robertson; Melvin E. Lazar; John M. Krochta; Daniel F. Farkas; John L. Bomben. Method of removing corn from the cob. 1976-04-27 Publication of US4107340A. URL: https://patents.google.com/patent/US4107340A/en.

4. Jonathan E. Ricketts. Dual action corn cob separation and corn cob separator. 2008-04-22. Publication of US20090264169A1. URL: https://patents.google.com/patent/US20090264169A1/en.

5. Redekop Leo, Mayerle Dean. Harvesting corn cobs. 2007-10-15. Publication of US20100193411A1. URL: https://patents.google.com/patent/US20100193411.

6. Кукурузоуборочные машины / К.В. Шатилов, Б.Д. Козачок, А.П. Орехов и др. М.: Машиностроение, 1981. 224 с.

7. Li, X. P. and Gao, L. X. (2007). Experimental study on breaking mechanism of kernel stem of corn seed. Transactions of the CSAE, 23: 47-51.

8. X, J., Li, X. F., Sun, L., Du, X. and Gao, L. X. (2009). Experiment on optimal forcing method for seed corn thresher, Trans. Chinese Soc. Agric. Mach. $4071-75,29$.

9. Gao, L. X., Li, F., Zhang, X. W., Zhang, Y. L., Liu, X. and Jiao, W. P. (2012). Mechanism of moisture content affect on corn seed threshing, Trans. Chinese Soc. Agric. Mach. 42 92-96, 42

10. Dominguez, H. D. A, Suhendro, E. L. and Rooney, L.W. (1997). Factors affecting rapid visco analyser curves for the determination of maize kernel hardness. Journal of Cereal Science, 25: 93-102

11. Szymanek, M. (2011). Effects of blanching on some physical properties and processing recovery of sweet corn cobs. Food and Bioprocess Technology, 4(7): 1164-1171.

12. Akritidis, C. B. 1974. The mechanical characteristics of maize stalks in relation to the characteristics of cutting blade. Journal of Agricultural Engineering Research, 19(1): 1-12.

13. Esehaghbeygi, A., B. Hoseinzadeh, and A. A. Masoumi. (2009). Effects of moisture content and urea fertilizer on bending and shearing properties of canola stem. Applied Engineering in Agriculture, 25(6): 947-951.

14. Prasad, J., and C. P. Gupta. (1975). Mechanical properties of maize stalk as related to harvesting. Journal of Agricultural Engineering Research, 20(1): 79-87.

15. Miu, P. 2016. Combine Harvesters Theory, Modeling, and Design. 1st ed. New York, USA: Taylor and Francis Group, LLC.

16. Сагомонян А.Я. Волны напряжения в силовых средах: учебное пособие. М., 1985. 416 с.

17. Al-Zube, L., Sun, W., Robertson, D., Cool, D. The elastic modulus for maize stems. Plant Methods, 14, 11 (2018). URL: https://doi.org/10.1186/s13007-018-0279-6

18. Ерофеев В.И., Кажаев В.В., Семерикові Н.П. . Волны в стержнях. Дисперсия. Диссипация. Нелинейность. М.: Физматлит, 2002. $208 \mathrm{c}$.

19. Szymanek, M. 2011. Effects of blanching on some physical properties and processing recovery of sweet corn cobs. Food and Bioprocess Technology, 4(7): 1164-1171.

20. Kaliyan, N., Morey, R. V. Densification characteristics of corn cobs. Fuel Processing Technology. 2010, 91, $559-565$. doi:10.1016/j.fuproc.2010.01.001

21. Al-Mitewty, M. I., A. Yahya, M. Razif, and N. Mat. 2019. Physical and mechanical properties of sweet corn plant. Agricultural Engineering International: CIGR Journal, 21(4): 152-160. 


\section{В. А. Грубань, В. І. Гавриш, А. В. Калініченко. Визначення сили для відділення качанів кукурудзи}

Проаналізовано способи відокремлення качанів кукурудзи від стебел. Досліджено фізичні та механічні властивості кукурудзи. Розроблено математичну модель визначення зусиль для відокремлення качана. Виконано верифікацію моделі з використанням експериментальних даних. Встановлено, що хвильова математична модель дає більш точні результати. Розроблена математична модель може бути використана для розробки конструкції качановідокремлювальних апаратів кукурудзозбиральних машин.

Ключові слова: кукурудза, качан, система сепарації качанів, математична модель.

\section{В. А. Грубань, В. И. Гавриш, А. В. Калиниченко. Определение силы для разделения початков кукурузы}

Проанализированы способы отделения початков кукурузы от стеблей. Изучены физические и механические свойства кукурузы. Разработана математическая модель определения усилий для отделения початка. Выполнена верификация математической модели $c$ использованием экспериментальных данных. Установлено, что волновая математическая модель дает более точные результаты. Разработанная математическая модель может быть использована для разработки конструкции початкоотделительных аппаратов кукурузоуборочных машин.

Ключевые слова: кукуруза, початок, система сепарации початков, математическая модель. 